\title{
HYPOPROTHROMBINEMIA IN THE COMPENSATED FORM OF HEPATOSPLENIC SCHISTOSOMIASIS: FURTHER STUDIES.
}

\author{
Nora MANOUKIAN \& Durval Rosa BORGES
}

\author{
S U M M A R Y
}

Coagulation abnormality is frequently observed in schistosomiasis patients but its pathophysiology has not been established. We measured, by immunodiffusion. the prothrombin-antigen concentration in 56 individuals: of these 19 with demonstrated compensated form of hepatosplenic schistosomiasis, 17 with cirrhosis and 20 were control subjects. Transaminases, albumin, transthyretin, prothrombin time. antithrombin III, factor VII, and fibrinogen were also evaluated.

All parameters were altered in the cirrhotic group but only albumin, prothrombin and antithrombin III levels were altered in the schistosomiasis group. Ninety percent of the patients with cirrhosis and sixty percent of the patients with schistosomiasis had abnormal plasma levels of albumin, transthyretin. prothrombin-antigen, and or antithrombin III; an impaired hepatic synthesis was responsible for these results.

Conversely forty percent of the schistosomiasis patients with normal plasma concentrations of both albumin and transthyretin had decreased mean plasma levels of both prothrombin and antithrombin III. These results suggest that either proth rombin and antithrombin III are more sensitive markers of impaired hepatic synthesis in schistosomiasis than are levels of albumin and transthyretin combined. or a low grade chronic consumption of clotting proteins also occurs. Considering the latter hypothesis it is possible that the thrombin formed would be inhibited by antithrombin III with the complexed thrombin-antithrombin III being cleared by the liver. Consequently the plasma levels of both prothrombin and antithrombin would be decreased, but the level of fibrinogen would be preserved.

KEY WORDS: Prothrombin; Antithrombin III: Schistosomiasis: Coagulopathy.

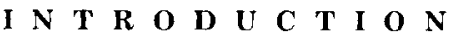

Over 200 million people worldwide suffer from schistosomiasis. This parasitic infection affects about $10 \%$ of the Brazilian population of 135 million inhabitants. Alterations in the plasma coagulation system are frequently detected in this disease, although the precise etiology is not well defined. ${ }^{2}{ }^{12}{ }^{13}$ These alterations may, however, be partially corrected by hepariniza- tion or surgical procedures which correct portal hypertension ${ }^{2}$.

Schistosomiasis and cirrhosis are the main causes of liver fibrosis in Brazil. In hepatic cirrhosis the alterations of the coagulation tests are usually attributed basically to the deficiency in the synthesis of coagulation factors. Other

Division of Gastroenterology, Department of Medicine "Escola Paulista de Medicina". Sào Paulo. SP . Brazil 
MANOUKIAN, N. \& BORGES. D. R. - Hypoprothrombinemia in the compensated form of hepatosplenic schistoso miasis: further studies. Rev. Inst. Med. trop. Sä Paulo. 30 (4): 274280.1988

purposed causes for these alterations have been suggested and these are deficiency in $\gamma$ carbo xylation of vitamin $\mathrm{K}$ dependent proteins, disfi brinogenemia, and chronic or slow consumption of coagulation factors ${ }^{8}$.

Unlike cirrhosis, in schistosomiasis portal hypertension is pre-sinusoidal and vascular alterations of the portal area may recede sponta neously or after chemotherapy ${ }^{1 / 2}$. In the hepa tosplenic form of schistosomiasis the evident portal hypertension is accompanied by preser vation of hepatic function ${ }^{15}$ whereas in cirrhosis. portal hypertension is accompanied in most cases with hepatocytic insuficiency. Thus, the stu dy of coagulation in schistosomiasis is impor tant because, in this disease there is, to a certain extent, a dissociation between hepatocytic function and portal hypertension.

In order to study alterations of coagulation in the hepatosplenic form of schistosomiasis, we measured the plasmatic levels of prothrombinantigen, antithrombin III (the main thrombin inhibitor) and fibrinogen (thrombin physiological substrate). We studied prothrombin because: 1) it is a protein synthesized by the liver: 2 ) it is not an acute phase protein: 3 l it influences decisively the results of the coagulation tests used in daily practice (prothrombin and partial thromboplastin times I: 4 ) and it has a central role in the coagulation cascade because on its activation depends not only the hydrolysis of fibrinogen but, also, in the activation of factors V. VIII, XIII, and protein C

Hepatic protein synthesis was assayed through determination of serum transthyretin and albumin. Only non-alcoholics (less than $10 \mathrm{~g}$ ethanol daily intake) and HBSAg negative (RIA) patients with schistosomiasis were chosen in order to avoid interference of the main factors which may lead to liver cirrhosis.

Two other groups of individuals, normal con trols, and others with cirrhosis, were included for the sake of comparison in the study. All indi viduals were not in an acute phase situation, as determined by the serum acid $\boldsymbol{\alpha}$-1-glycoprotein concentration, and were well nourished.

\section{CASES AND METHODS}

A total of 56 well nourished individuals (with an adequate weight-height relationship and from the same socio economic class were divided into 3 groups icontrol, schistosomiasis, and cirrhosis) and studied.

The control group (CON) consisted of 20 healthy volunteers ( 14 females) age 16-67 years (median 34 years): they were all non-alcoholics, HBsAg negatives and non-schistosomotics. The group with schistosomiasis ( $\mathrm{SCH}$ ) consisted of 19 individuals (12 males) aged $15-65$ years (me dian 35 years). Clinical and epidemiological diagnosis of schistosomiasis was confirmed by the presence of eggs of $\mathbf{S}$. mansoni in the faeces or by biopsy of rectal valves. The size of the liver varied between 1 and $8 \mathrm{~cm}$ istarting from the border of the last right rib), and that of the spleen between 1 and $20 \mathrm{~cm}$ istarting from the border of the last left rib). All these patients presented the compensated form of hepatosplenic schisto somiasis, with no jaundice, ascites, edema or signs of bleeding.

The cirrhotic (CIR) group consisted of 17 in dividuals ( 14 males), age 30-63 years (median 46 years). Twelve of these patients were alcoholics with a mean ethanol intake of $142 \mathrm{~g}$ /day for a period varying from 7 to 35 years (median 25 years). The 5 other cirrhotics were non-alcoho lics, but HBsAg positives. The clinical diagnosis of hepatic cirrhosis was confirmed in all cases by liver histological findings. None of the pa tients presented ascites, edema, signs of encephalopathy or bleeding, and could be classified as Child $\mathrm{A}^{16}$.

Blood was collected using the double-syrin ge technique. Following this technique, after ve nous puncture the first syringe containing 1 to $2 \mathrm{ml}$ of blood was substituted by a second syringe adapted to the same needle. This technique aims to avoid the presence of thromboplastic materia from the puncture itself into the plasma that is to be assayed.

Prothrombin time and prothrombin antigen, antithrombin III, fibrinogen, and factor VII levels, were determined in citrated plasma ( 9 parts of blood: 1 part of sodium citrate $0,109 \mathrm{M}$ ) Albumin was determined in serum by the bromocresol purple technique ${ }^{7}$ and the total protein content by the biuret method ${ }^{5}$. Serum transa minases and $\boldsymbol{\gamma}$-glutamyltransferase were deter mined by kits (n: $124419,124567,125931$, respec 
MANOUKIAN. N. \& BORGES. D. R. - Hypoprothrombinemia in the compensated form of hepatosplenic schistoso miasis: further studies. Rev. Inst. Med. trop. Sáo Paulo, 30 (4): $274280,1988$.

tively) from Boehringer Mannheim. Serum transthyretin, $\boldsymbol{\alpha}_{1}$ acid glycoprotein, plasma fibri nogen, prothrombin-antigen were assayed by ra dial immunodiffusion, utilizing $M$. Partigen pla tes (Boehringwerke A.G., Marburg, W. Germany), employing standards from the same source The antibody used for prothrombin antigen re cognizes both forms of prothrombin ( $\gamma$ and non $\gamma$ carboxilated forms). Antithrombin III was as sayed through residual thrombin activity after incubation with an excess of thrombin using the synthetic substrate Tos-Gly-Pro-Arg-pNA (Boehringer Mannhein GmBH, W. Germany). Factor VII was assayed with the use of human factor VII deficient plasma; 40 to $160 \mathrm{U} \mathrm{ml}$ were considered normal values ${ }^{14}$. A pool of plasma from the control group was used to establish the reference curve. Prothrombin time was measu red using human brain thromboplastin ${ }^{13}$ with the results being expressed as a ratio. In all 56 individuals $\mathrm{HBSAg}$ was tested by radioimmu noassay ( RIA).
Comparison of the results of the different de terminations in the 3 groups was performed by analysis of variance at a level of significance $p$ $<0,05$. Scheffe's test was used when there was a statistically significant difference.

Cut-off values for each determination were established using the results of the control group in order to discriminate these individuals from those of the two groups ${ }^{1 / 2}$. This procedure allowed for the classification of the results of the assays either as normal or altered.

\section{RESULTS}

The results (mean $\pm \mathrm{SE}$ ) of the different de terminations are shown in Table 1 . The cirrhotic group results were statistically different from those of the control and schistosomiasis groups. Results for albumin, prothrombin and antith rombin III of the schistosomiasis group were sta

TABLE 1

Comparison of clotting and biochemical tests.

\begin{tabular}{|c|c|c|c|c|}
\hline Group & $\begin{array}{l}\text { Control } \\
n=20 \\
M=S E\end{array}$ & $\begin{array}{c}\text { Schistosomiasis } \\
\qquad \begin{array}{c}n=19 \\
M+S E\end{array}\end{array}$ & $\begin{array}{c}\text { Cirrhotic } \\
n=17 \\
M \pm S E\end{array}$ & $\begin{array}{l}\text { Variance } \\
\text { Analysis }\end{array}$ \\
\hline $\begin{array}{l}\text { Aspartate aminotransferase } \\
\mathrm{U} / \mathrm{L}\end{array}$ & $17 \pm 2$ & $24+3$ & $60 \pm 7$ & $\mathrm{CIR}>\mathrm{SCH}=\mathrm{CON}$ \\
\hline $\begin{array}{l}\text { Alanine aminotransferase } \\
\mathrm{U} / \mathrm{L}\end{array}$ & $14 \pm 1$ & $24 \div 4$ & $39+6$ & $\mathrm{CIR}>\mathrm{SCH}=\mathrm{CON}$ \\
\hline $\begin{array}{l}\text { Total bilirubin } \\
\mathrm{mg} / \mathrm{dl}\end{array}$ & $0.7 \pm 0.05$ & $1.0+0,06$ & $2.6 \pm 0.57$ & $\mathrm{CIR}>\mathrm{SCH}=\mathrm{CON}$ \\
\hline $\begin{array}{l}\gamma \text { Glutamyl-transferase } \\
\mathrm{U} / \mathrm{L}\end{array}$ & $20 \pm 2,5$ & $44 \pm 6,1$ & $142+36,7$ & $\mathrm{CIR}>\mathrm{SCH}=\mathrm{CON}$ \\
\hline $\begin{array}{l}\text { Albumin } \\
\mathrm{g} / \mathrm{L}\end{array}$ & $39,2 \pm 0.7$ & $35.9 \pm 0.9$ & $28.6 \pm 1,3$ & $\mathrm{CIR}<\mathrm{SCH}<\mathrm{CON}$ \\
\hline $\begin{array}{l}\text { Transthyretin } \\
\mathrm{mg} / \mathrm{L}\end{array}$ & $257 \pm 6,7$ & $229 \pm 12,4$ & $175 \pm 18$ & $\mathrm{CIR}<\mathrm{SCH}=\mathrm{CON}$ \\
\hline $\begin{array}{l}\text { Fibrinogen } \\
\mathrm{g} / \mathrm{L}\end{array}$ & $3,4 \pm 0.8$ & $3.5 \pm 0.13$ & $2,8 \pm 0,17$ & $\mathrm{CIR}<\mathrm{SCH}=\mathrm{CON}$ \\
\hline Prothrombin time ratio & $1.00 \pm 0.03$ & $1.08 \pm 0.04$ & $1.33 \pm 0.08$ & $\mathrm{CIR}<\mathrm{SCH}=\mathrm{CON}$ \\
\hline $\begin{array}{l}\text { Prothrombin-antigen } \\
\mathrm{mg} / \mathrm{L}\end{array}$ & $94 \pm 4,4$ & $52 \pm 2,9$ & $37 \pm 2,8$ & $\mathrm{CIR}<\mathrm{SCH}<\mathrm{CON}$ \\
\hline $\begin{array}{l}\text { Antithrombin III } \\
\mathrm{U} / \mathrm{ml}\end{array}$ & $23 \pm 0.7$ & $19 \pm 0,9$ & $14 \pm 1.7$ & $\mathrm{CIR}<\mathrm{SCH}<\mathrm{CON}$ \\
\hline $\begin{array}{l}\text { Factor VII } \\
\mathrm{U} / \mathrm{ml}\end{array}$ & - & $78 \pm 3.1$ & $51 \pm 4,9$ & $\mathrm{CIR}<\mathrm{SCH}$ \\
\hline
\end{tabular}

* CIR: Cirrhotic group; $\mathrm{SCH}$ : Schistosomiasis group: CON: Control group. 
MANOUKIAN, N. \& BORGES, D. R. - Hypoprothrombinemia in the compensated form of hepatosplenic schistoso miasis: further studies. Rev. Inst. Med. trop. Sáo Paulo, 30 (4): 274-280.1988.

tistically different from those of the control group.

On the basis of the established cut-off values (Table 2), it was observed that the proteins which were altered in the greatest number of patients were albumin, transthyretin, prothrombin-anti. gen, and antithrombin III.
The schistosomiasis group may be thus divi ded in to two sub-groups: one showed altered al bumin and/or transthyretin values ( 10 patients) and other with normal albumin and transthy retin values. It is noteworthy that even this latter group presented lower mean prothrombin and antithrombin III values than the control group (Table 3)

TABLE 2

Critical levels for each test and number of patients showing altered results

\begin{tabular}{lccc}
\hline & $\begin{array}{c}\text { Critical } \\
\text { Levels }\end{array}$ & $\begin{array}{c}\text { Number of } \\
\text { Schistosomotics } \\
\text { With Altered } \\
\text { Results }\end{array}$ & $\begin{array}{c}\text { Number of } \\
\text { Cirrhotics With } \\
\text { Altered Results }\end{array}$ \\
\hline Albumin & $33 \mathrm{~g} / \mathrm{L}$ & 6 & 13 \\
Transthyretin & $220 \mathrm{mg} / \mathrm{L}$ & 7 & 12 \\
Albumin and Transthyretin & - & 10 & 15 \\
Fibrinogen & $3,4 \mathrm{~g} / \mathrm{L}$ & 0 & 1 \\
Prothrombin-time & 1,00 & 3 & 17 \\
Prothrombin-antigen & $95 \mathrm{mg} / \mathrm{L}$ & 11 & 12 \\
Antithrombin III & $23 \mathrm{U} / \mathrm{mL}$ & 0 & 5 \\
Factor VII & $40 \mathrm{U} / \mathrm{mL}$ & 11 & 17 \\
\hline
\end{tabular}

TABLE 3

Comparison of antithrombin III and prothrombin mean values in 9 schistosomiasis patients with normal albumin and trans thyretin

\begin{tabular}{|c|c|c|c|}
\hline & $\begin{array}{c}\text { Control } \\
\mathrm{n}=20 \\
\text { Mean } \pm \mathrm{SE}\end{array}$ & $\begin{array}{c}\text { Schistosomiasis } \\
n=9 \\
\text { Mean } \pm \mathrm{SE}\end{array}$ & $\begin{array}{l}\text { Student " } t " \\
\text { Test }\end{array}$ \\
\hline $\begin{array}{l}\text { Prothrombin antigen } \\
\mathrm{mg} / \mathrm{L}\end{array}$ & $95 \pm 4,5$ & $76 \pm 2.9$ & $\mathrm{p}<0,05$ \\
\hline $\begin{array}{l}\text { Antithrombin III } \\
\text { UimL }\end{array}$ & $23 \pm 0.7$ & $20 \pm 0.8$ & $\mathrm{p} \propto 0,05$ \\
\hline $\begin{array}{l}\text { Albumin } \\
\mathrm{g} \mathrm{L}\end{array}$ & $39 \pm 0.7$ & $38 \pm 0,8$ & NS \\
\hline $\begin{array}{l}\text { Transthyretin } \\
\mathrm{mg} \mathrm{L}\end{array}$ & $257 \pm 6,7$ & $272 \pm 7.7$ & NS \\
\hline
\end{tabular}

\section{DISCUSSION}

In the present work we studied prothrombin-antigen as well as other clotting plasma proteins in schistosomiasis patients. In order to mi nimize the possibility of including patients with cirrhosis in the schistosomiasis group we exclu ded from it patients who may be carriers of
HBsAg as well as alcoholics. The reason for this is the fact that there's a high incidence of alcoho lism and schistosomiasis in the Brazilian popula tion, and of virus B carriers in hepatosplenic schistosomiasis patients ${ }^{11}$.

Transaminases and $\boldsymbol{\gamma}$-glutamyltranferase as well as bilirubins showed the expected values in the schistosomiasis infected and cirrhotic sub jects.

In order to evaluate hepatic protein synthesis we included in the study only well nourished individuals and those that were not in acute phase situation because it is well known that both fac tors interfere with normal protein synthesis. The liver function of protein synthesis was evaluated through serum content of albumin (half-life 20 days) and transthyretin (half-life 48 hours) ${ }^{6}$. The latter has a half-life similar to that of antithrombin III ( 42 hours), but being shorter than that of prothrombin ( 86 hours), fibrinogen ( 92 hours) and longer than that of factor VII ( 5 hours $)^{20}$. 
MANOUKIAN. N. \& BORGES. D. R. - Hypoprothrombinemia in the compensated form of hepatosplenic schisteso miasis: further studies. Rev. Inst. Med. trop. Säo Paulo. 30 (4): 274280.1988.

On analysis of the mean values found for each kind of determination the schistosomiasis group could be differentiated from the control only by comparing the levels of albumin, prothrombin, and antithrombin III: the cirrhotics differed from the other two groups in regard to all assays.

Values obtained in the control group allowed the establishment of a reference range and, thus, each patient could be individually evaluated. Prothrombin-antigen was the protein found to be lowered in the greatest number of schistosomiasis patients. Its value was shown to be alte red in all cirrhotics.

Prothrombin time, being a less sensitive as say than the immunologic determination of prothrombin, differentiated fewer patients in both groups.

Despite the fact that factor VII has a shorter half life than does prothrombin, its values were altered in only 5 cirrhotics but in none of the schistosomiasis patients. This low sensitivity of factor VII determination can be explained as a consequence of the biological method used.

Decrease in fibrinogen was only found in one patient with cirrhosis. This agrees with findings cited in the literature stating that fibrinogen values are altered only in severe liver disease ${ }^{4}$.

Regarding hepatic protein synthesis it was observed that transthyretin values discriminated the greatest number of patients in the schistosomiasis group in spite of the fact that the mean values of transthyretin were not statistically different from that of the control group. This may be due to the great dispersion of the values found in the schistosomiasis infected group. It should be noted that in this group both mean albumin and transthyretin values were decreased by $10 \%$ in relation to that of the control group

Besides discriminating a greater number of schistosomiasis patients, transthyretin could be more specific in evaluating hepatic protein syn thesis because nonspecific decreased albumin content, secondary to increase in $\gamma$-globulin, has been described ${ }^{9}$. In fact we could observe an inverse significant correlation $(r=-0,672, p$

0.05 , between serum albumin and globulns in schistosomiasis patients.

On the basis of the results of albumin and transthyretin determinations it can be said that in at least $90 \%$ of the patients with cirrhosis and in $60 \%$ of the schistosomiasis patients, the alterations of the coagulation parameters were se condary to deficiency of hepatocy tic protein syn thesis. Conversely, $40 \%$ of these schistosomiasis patients with apparent normal synthesis (normal values of albumin and transthyretin) showed a decrease of the mean plasmatic levels of prothrombin-antigen and antithrombin III. This finding can be interpreted in at least two ways: firstly prothrombin-antigen and antithrombin III are more sensitive than are albumin and transthyretin in evaluating hepatic protein synthesis. It should be noted however, that transthyretin has a shorter half-life than does prothrombin-antigen, being similar to that of antithrombin III; secondly a qualitatively altered synthesis or increased consumption of coagulation factors might account for the results. In cirrhosis an altered synthesis of fibrinogen with consequent decrease in its half-life has been described $^{3}$. No reference to disfibrinogenemia in hepatosplenic schistosomiasis has been reported but we have previously shown indirectly the existence of non-rcarboxylated prothrombin in this disease $^{12}$. Another mechanism which could explain a decrease in coagulation factors would be a slow and chronic consumption which would surpass the liver functional reserve.

VERSTRAETE et al. ${ }^{19}$ suggest that the slow. ness of the spleno-portal flow in cirrhotics would favour activation of the contact system of coagulation. In an earlier paper ${ }^{13}$ we showed a decrease of pre-kallirein in hepatosplenic schistosomiasis patients with normal albumin and transthyretin values.

A slow and chronic prothrombin activation would lead to formation of thrombin which would be inhibited by antithrombin III, with the resulting complex being cleared by the liver ${ }^{10}$ before hydrolyzing fibrinogen. This hypothesis could explain the preservation of fibrinogen plasma levels concomitant with decrease in cir- 
MANOUKIAN, N. \& BORGES, D. R. - Hypoprothrombinemia in the compensated form of hepatosplenic schistoso miasis: further studies. Rev. Inst. Med. trop. São Paulo, 30 (4): 274-280, 1988.

culating levels of prothrombin and antithrombin III.

\section{RESUMO}

Hipoprotrombinemia na forma-compensada da esquistossomose hepatoesplênica: novos estudos

Alteraçōes na coagulaçāo são frequentemente observadas em portadores da esquistossomose, mas sua fisiopatologia ainda nāo foi estabelecida. Medimos, por imunodifusão, a concentraçāo da protrombina-antígeno em 56 indivíduos: 19 com a forma compensada da esquistossomose hepatoesplênica 17 com cirrose e 20 sadios. Foram também determinadas transaminases, albumina, transtiretina, tempo de protrombina, antitrombina III, fator VII e fibrinogênio.

As médias de todos os parâmetros estavam alteradas no grupo cirrótico mas apenas as de albumina, protrombina e antitrombina III no grupo esquistossomótico. Noventa por cento dos portadores de cirrose e $60 \%$ dos portadores de esquistossomose tinham níveis plasmáticos diminuídos de albumina, transtiretina, protrombina e/ou antitrombina III; sintese hepática diminuída pode explicar estes resultados.

Por outro lado, em $40 \%$ dos portadores de esquistossomose com concentraçōes plasmáticas de albumina e transtiretina normais as concentraçōes médias de protrombina e antitrombina III estavam diminuídas. Estes resultados sugerem que a protombina e antitrombina III são marcadores mais sensiveis de sintese hepática do que o conjunto albumina/transtiretina ou que um consumo crônico das proteínas da coagulação ocorra. Considerando esta última possibilidade é possivel supor-se que a trombina formada seja inibida pela antitrombina III e o complexo trombina-antitrombina III depurado pelo fígado. Consequentemente os níveis plasmáticos de protrombina e antitrombina III diminuem mas o do fibrinogênio é preservado.

\section{REFERENCES}

1. ANDRADE, Z. A. \& BRITO, P. A. - Evolution of schisto somal hepatic vascular lesion after specific chemoterapy Amer. J. Trop. Med. Hyg., 30: 1223-1227, 1981
2. BORGES, D. R.: VILELA, M. P. \& GUERRA, C. C. C - Haemostasis in schistosomiasis mansoni. Gen, 31 $165-177,1977$

3. COLEMAN, M.; FINLAYSON N ; BETTIGALE, R. E ; SA DULA, D : COHN, M \& PASMANTIER, M - Fibrinogen survival in cirrhosis: Improvement by "low dose" heparin. Ann. intern. Med.; 83: 79.81, 1975

4. COLMAN, R. W. \& RUBIN, R. N. - Blood coagulation In: ARIAS, J.; POPPER, H : SCHAFTER, D. \& SHA FRITZ, D. A., ed. - The liver: biology and pathobiology New York, Raven Press, 1982. p. 761.769

5. GORNALL, A. G.; BARDAWILL, C. J. \& DAVID, M. A - Determination of serum proteins by means of the biuret reaction. J. Biol. Chem., 177: 751.766. 1949

6. HAIDER, M \& HAIDER, S. Q. - Assessment of protein caloric malnutrition. Clin. Chem., 30: 1286 1299, 1984

7. HILL, P. G. \& WELLS, T. N. C. - Bromocresol purple and the measurement of albumin Ann. clin. Biochem. 20: $264-270,1983$

8. KELLY, D. A. \& TUDDENHAM, E. G. D. - Haemostatic problems in liver disease. Gut, 27 : 339349,1986

9. KESHGEGIAN, A. A. - Hypoalbuminemia associated with diffuse hyperglobulinemia in chronic diseases: lack of diagnostic specificity. Amer. J. clin. Path., 81: 477481 , 1984

10. LOLLAR, P. \& OWEN, W. G. - Clearance of thrombin from circulation in rabbits by high affinity binding sites on endothelium. J. clin. Invest., 66: 1222-1230, 1980.

11. LYRA, L. G.; REBOUÇAS, G. \& ANDRADE, Z. A. - He patitis $B$ surface antigen carrier state in hepatosplenic schistosomiasis. Gastroenterology, 71: 641-645, 1976.

12. MANOUKIAN, N \& BORGES, D. R. - Avaliaçāo funcio nal e imunológica da protrombina na forma hepatoesplé nica da esquistossomose e na cirrose hepática. Rev. paul. Med., 101: 182-185, 1983.

13. MANOUKIAN, N. \& BORGES, D. R. - Pre albumin, pre kallikrein and prothrombin in hepatosplenic schistoso miasis: Increased turnover of the clotting proteins? Rev. Inst. Med. trop. S. Paulo, 26: 237 240, 1984

14. NEMERSON, Y. \& CLYNE, L. P. - - An assay for coagu lation factor VII using factor VII depleted bovine plasma. J. Lab. clin. Med., 83: 301 303, 1974

15. RAMOS, O. L.; SAAD, F. \& LESER, W. P. - Portal hemody namics and liver cell function in hepatic schistosomiasis Gastroenterology, 47: 241-247, 1964 
MANOUKIAN, N. \& BORGES. D. R. - Hypoprothrombinemia in the compensated form of hepatosplenic schist uso miasis: further studies. Rev. Inst. Med. trop. São Paulo, 30 (4): 274-280, 1988.

16. SHERLOCK, S. - Hepatic cirrhosis. In: SHERLOCK, S - Disease of the liver and biliary system. $7^{\text {th }}$ ed. Oxford, Blackwell Scientific Publication, 1985, p. 334345

17. SLEIGH, A. C.: HOFF, R.: MOTA. E. A.: SHERLOCK I.; MOTT, K. E.: BARRETO. M. L.: MAGUIRE, J. H. \& WELLER, T. H. - Three years prospective study of evolu tion of Manson's schistosomiasis in North East Brazil Lancet, 2: 6366,1985

18. STEINBERG, W. M.; GOLDSTEIN, S. S.: DAVIS, N. D.: SHAMMA'A, J. \& ANDERSON, K. - Diagnosis assay in acute pancreatitis: a study of sensitivity and specificity Ann. intern. Med., 102: 576-580. 1985.
19. VERSTRAETE $M$ - VERMYLEN S \& COLLEN D Intravascular coagulation in liver disease Ann. Rev. Med. 25: $447-455,1974$

20. WINTROBE, M. M.: LEE, G. R.: BOGGS, D. R.: BI THELL. T. C., FOERSTER, J.; ATHENS. J. W. \& LU KENS. J N - Blood coagulation. In: WINTROBE. M. M. LEE G. R.: BOGGS, D. R.: BITHELL, T. C : FOERS TER, J. ATHENS, J. W. \& LUKENS. J. N - Clinical haematology. $8^{\text {th }}$. ed. Philadelphia. Lea \& Febiger, 1981. p. 405.452

Recebido para publicaçào em 09:3 1988. 